\title{
Unravelling the Trade and Environment Debate through Sustainable Development Law Principles
}

\author{
Francesco Sindico*
}

\section{Introduction}

The trade and environment debate conceals the conflictive relationship between two legitimate interests of the international community: the international protection of the environment ${ }^{1}$ and the liberalization of international trade. One of the central issues of the debate is the difficult relationship between Trade Related Environmental Measures (hereinafter 'TREMs') in Multilateral Environmental Agreements (hereinafter 'MEAs') and World Trade Organization (WTO) norms. The international community must find a way to balance environmental and trade interests therein. However, a simultaneous effort to reconcile extreme positions in the more general trade and environment debate must also be undertaken.

Against this background, this article pursues three main goals. First, it wants to determine if public international law rules can be used in the WTO framework. Second, it wants to see whether sustainable development and its principles have developed into a norm of international law. Third, it wants to determine whether sustainable development law may be useful to find a balance between TREMs in MEAs and WTO norms.

\section{Public International Law and the World Trade Organization}

The main aim in this part of the paper is to determine whether public international law can be used in the WTO. In order to reach a conclusion on this point we will first analyse the relationship between TREMs in MEAs and the rules of the multilateral trading system.

\section{A. Relationship between Trade Measures in Multilateral Environmental Agreements and the WTO}

International trade may affect the environment in two ways. On the one hand, specific substances may be very dangerous for the environment (such as hazardous wastes, chemicals, pesticides, etc...), and international trade of such products must be strictly regulated. On the other hand, the environment can also be damaged if international trade of specific natural resources (such as particular animal species, biodiversity elements, etc...) is not regulated.

Francesco Sindico is a PhD candidate in International Law at the Universitat Jaume I, Castellón de la Plana, Spain. He holds a fellowship from the Spanish Ministry of Education (project number BJU2003-00346) and he is a former EU Marie Curie Fellow from September, 2003 to March, 2004 (contract number: EVK2-CT-2002-57006) at the Institute for Environmental Studies, Faculty of Earth and Life Sciences, Vrije Universiteit, Amsterdam, the Netherlands. Francesco Sindico can be contacted at sindico@dpu.uji.es.

1 The obligation to protect the environment is a norm of international law. This has been clarified by the International Court of Justice (ICJ) in its Advisory Opinion Legality of the Threat or Use of Nuclear Weapons, 1996, § 29. 
Therefore, several MEAs, ${ }^{2}$ in order to protect the environment, provide for TREMs, which are measures that ban, limit or affect in other ways international trade. These measures may be incompatible with WTO rules and, therefore, lead to a conflict of norms and of jurisdictions.

States, authors and other stakeholders have been dealing thoroughly with the relationship between TREMs in MEAs and the WTO in the last ten years. No clear solution or agreement has been reached. ${ }^{3}$ There have been three main approaches to the issue: a WTO approach; an extraWTO approach and a cooperative approach.

\section{The WTO Approach}

The WTO approach recognises the importance and the strength of the multilateral trading system and, therefore, it tries to find a solution to the trade and environment debate therein.

A first option provides for the amendment of General Agreement on Tariffs and Trade (hereinafter 'GATT') Art. XX in order to enable measures taken in accordance with MEA provisions to be WTO compatible. ${ }^{4}$ A second option requires the WTO Ministerial Conference to give an official interpretation of Art. XX of the GATT. ${ }^{5}$ The understanding shall clarify that TREMs in MEAs are legitimate and necessary, notwithstanding their need to be nondiscriminatory. ${ }^{6}$ A third option provides for WTO waivers for specific MEAs. ${ }^{7}$ This option would have the same effect as the previous one but waivers would have to be renewed every year. ${ }^{8} \mathrm{~A}$ fourth option is the reversal of the burden of proof in Art. XX of the GATT. While currently the party that applies the TREM must prove its legitimacy and necessity, according to this option the

2 According to Doc. WT/CTE/W/160/Rev.2 Matrix on Trade Measures Pursuant to Selected Multilateral Environmental Agreements (2003), pp. 127-129, there are 28 MEAs that contain potential trade measures.

3 Doc. TN/TE/S/1, Multilateral Environmental Agreements (MEAs) and WTO rules; Proposals made in the Committee on Trade and Environment (CTE) from 1995-2002 Note by the Secretariat (2002), summarizes the proposals made by WTO members in the Committee on Trade and Environment in order to solve the conflict between TREMs in MEAs and the WTO.

4 See T. J. Schoenbaum, "International Trade and Protection of the Environment: The Continuing Search for Reconciliation”, 91.2 AJIL (1997), p. 283-284 and 312.

5 In accordance with the procedure provided for in Art. IX.2 of the Marrakech Agreement Establishing the World Trade Organization.

6 This position is supported by the EU; see European Communities, Non Paper, February 19, 1996, quoted in Doc. TN/TE/S/1, op. cit.., p. 9; and by important scholars, such as P.T. Stoll, "How to Overcome the Dichotomy between WTO Rules and MEAs?", 63.2 Heidelberg Journal of International Law ZaöRV (2003), pp. 449-450 and p. 453; and F. Biermann, "The Rising Tide of Green Unilateralism in World Trade Law Options for Reconciling the Emerging North-South Conflict", 35.3 Journal of World Trade (2001), pp. 437-440 and 442-444.

7 In accordance with the procedure provided for in Art. IX.3 of the Marrakech Agreement Establishing the World Trade Organization.

8 T. J. Schoenbaum... op. cit., p. 283; F. Biermann... op. cit., p. 437; and P.T. Stoll... op. cit., pp. 450-451 y 453 criticises this option. On the other hand Hong Kong, ASEAN and New Zealand favour the WTO waiver option; see Doc. TN/TE/S/1... op. cit., p. 8, p. 12 and pp. 11-12. 
burden would fall on the party affected by the measure. ${ }^{9}$ A last option maintains that the current state of the multilateral trading system and of the WTO jurisprudence already accommodates in the best possible way environmental concerns. According to this position, there is no need for any modification of the WTO system. ${ }^{10}$

All these options, except for the last one, agree on the need to give TREMs in MEAs a legal presumption of environmental necessity in the WTO legal framework. ${ }^{11}$

\section{Extra WTO Approach}

The second way to solve the conflict between TREMs in MEAs and the WTO is the extra WTO approach. Those who suppot this position do not consider the multilateral trading system to be the right place to solve the conflict. They argue that a solution must be found outside of this organisation.

In the first place, they argue that MEAs and their institutions, in particular MEAs' non compliance procedures and dispute settlement systems, must be strengthened. Environmental concerns would then be dealt with in environmental foras, according to this approach. A second position is based on the assumption that if the WTO fails to address environmental concerns, it is because it has not been established for that purpose. This entails that a new international organisation that is able to counterbalance the WTO in the environmental field, a Global Environmental Organization, is needed. ${ }^{12}$

\section{Cooperative Approach}

The third way to solve the conflict between TREMs in MEAs and the WTO is the cooperative approach. On the one hand, better and increased cooperation between MEA Secretariats, the WTO Committee on Trade and Environment and the United Nations Environment Programme has been suggested. On the other hand, more visibility to environmental experts in WTO panels, when trade and environment interests are at stake, has been proposed. ${ }^{13}$

9 This option has been suggested by the EU; see Doc. WT/CTE/W/170, Resolving the Relationship between rules and Multilateral Environmental Agreements, Submission by the European Community (2000), § 10 and 15.

10 This was the position of Egypt, India and of the United States of America within the WTO Committee o Trade and Environment; see Doc. TN/TE/S/1... op. cit., p. 6 and 9.

11 On this important point see P.T. Stoll... op. cit., pp. 449-450 and p. 453.

12 See for example C. Ford Runge, "A Global Environmental Organization (GEO) and the World Trade System", 35.4 Journal of World Trade (2001), pp. 422. Linked to this second position an even more radical proposal has been proposed, according to which trade and environment interests would be dealt with better in an organisation dedicated to the achievement of Sustainable Development as a whole: a Global Sustainable Development Organization; see D. Luff, "An overview of international law of sustainable development and a confrontation between WTO rules and sustainable development", 29.1 Revue Belge de Droit International (1996), pp. 139-141

13 Cooperative approaches have been suggested for example by Japan and New Zealand; see Doc. TN/TE/S/1... op. cit., p. 15 and 16. 


\section{B. Public International Law in the Trade and Environment Debate}

We have seen that the conflict between TREMs in MEAs and the WTO leads to a conflict of norms and of jurisdictions. Is there any space for public international law in the solution to these conflicts? The answer can be found in the Vienna Convention on the Law of Treaties, ${ }^{14}$ which rules how to deal with competing treaties. Art. 30 thereof deals with the application of successive treaties relating to the same subject-matter and it maintains that the most recent one will prevail. This is the lex posterior rule. However, if the latter is applied rigorously, any MEA prior to 1994 that deals also with international trade will be subordinated to the Marrakech Agreement Establishing the World Trade Organization (hereinafter 'the Marrakech Agreement'), ${ }^{15}$ Therefore, we must see if there are other international law rules that deal with the interpretation of competing treaties that could help us in the solution of the trade and environment debate. A customary law rule, the lex specialis, is useful to solve this problem. According to this rule, if two treaties deal with the same issue, the most specific prevails over the more general treaty. Therefore, the lex specialis opens the door to the primacy of those MEAs that deal with international trade, such as the Cartagena Biosafety Protocol to the Convention of Biological Diversity (trade in genetically modified organisms), or the Convention on International Trade in Endangered Species of Wild Fauna and Flora (trade in wildlife species), over WTO rules. This entails that public international law, through the lex specialis rule, would settle a conflict of jurisdictions, due to a conflict of norms between MEA and WTO provisions, in favour of the environmental fora.

However, the current strength of the WTO and of its Dispute Settlement Body (hereinafter 'DSB') makes it very likely that trade and environment related disputes will fall under the WTO jurisdiction. What will happen if the dispute is brought before a WTO panel? Can public international law be used before the WTO settlement system? ${ }^{16}$ The WTO does not live in clinical isolation from international law. ${ }^{17}$ Even with all its particularities, WTO law and International Economical Law must be considered as international law applied to Economics. ${ }^{18}$ The WTO Understanding on Rules and Procedures Governing the Settlement of Disputes (hereinafter 'WTO Dispute Settlement Understanding') further underlines this issue maintaining that WTO provisions must be clarified 'in accordance with customary rules of interpretation of public international law'. ${ }^{19}$ Therefore, panels and appellate bodies must not only use WTO law to solve the disputes brought before them, but they can also use norms of public international law.

\section{Sustainable Development and Public International Law}

14 UN Doc. A/CONF.129/15, Vienna Convention on the Law of Treaties, Vienna, 23 May 1969, in force on January 27, 1980, printed in 25 INTERNATIONAL LAWM (1986), at 543.

15 Marrakech Agreement Establishing the World Trade Organization, 15 of April, 1994.

16 On this point see J. Pauwelyn, "The Role of Public International Law in the WTO: How far can we go?", 95 AJIL (2001), pp. 535-578.

17 Doc. WT/DS2/AB/R Appellate Body Report: United States - Standards for Reformulated and Conventional Gasoline, 1996, p. 621.

$18 \quad$ P. Weil already maintained this in 1973 ; see P.Weil quoted by P.M. Dupuy, "Où en est le droit international de l'environnement à la fin du siècle?", 101.4 RGDIP (1997), pp. 873-901, at 899.

19 WTO Understanding on Rules and Procedures Governing the Settlement of disputes, Art. 3.2. 
In the previous part of this paper we have clarified that public international law is important to the WTO. Furthermore, we have argued that it can play a relevant role in the solution of conflicts of norms and of jurisdictions, which arise from the relationship between TREMs in MEAs and WTO rules. The second goal of this paper is to determine whether sustainable development and its principles are norms of international law. In order to reach a conclusion on this difficult point we will try, firstly, to give a definition of sustainable development and, secondly, we will analyse the evolution of the legal nature of sustainable development and of its principles.

\section{A. Definition of Sustainable Development}

What is sustainable development? According to the Brundtland Report, it is: 'development that meets the needs of the present without compromising the ability of future generations to meet their own needs'. ${ }^{20}$ Recently, the International Law Association (hereinafter 'ILA') created a Committee on the Law of Sustainable Development. The final result of the Committee's work was issued in 2002, a document titled the New Delhi Declaration on the Law of Sustainable Development (hereinafter 'the New Delhi Declaration'). ${ }^{21}$ This document outlines a more complete definition of sustainable development, ${ }^{22}$ and it lists the principles, which constitute the law of sustainable development. This list includes among others the precautionary principle and the common but differentiated responsibilities principle.

In conclusion, sustainable development can be considered as a global development model that entails linkages between economic, social and environmental policies that will allow future generations to continue to develop.

\section{B. Evolution of Sustainable Development}

Whereas sustainable development was used officially for the first time within the international community in 1988, at the United Nations Conference on Environment and Development held in Rio in 1992, it was already a dominant issue. Sustainable development was present in all Rio

documents, ${ }^{23}$ and MEAs, such as the Convention on Biological Diversity, helped sustainable

20 World Commission on Environment and Development, Our Common Future, Oxford: Oxford University Press, (1987).

21 UN Doc. A/57/329, New Delhi Declaration of Principles of International Law Relating to Sustainable Development, 31 of August, 2002. On the New Delhi Declaration see A.B.M. Marong, "From Rio to Johannesburg: Reflections on the Role of International Legal Norms in Sustainable Development", 16 Georgetown International Environmental Law Review (2003), pp. 21-76, at 59-64; M-C.C. Segger; A. Khalfan; M. Gehring; M. Toering, "Prospects for Principles of International Sustainable Development Law after the WSSD: Common but Differentiated Responsibilities, Precaution and Participation", 12.1 RECIEL (2003), pp. 54-68, at 54-55.

$22 \quad$ Ibid, preamble $\S 13$.

23 The Rio documents are the Rio Declaration on Environment and Development, Agenda 21, the Statement of principles to guide the management, conservation and sustainable development of all types of forests, the United Nations Framework Convention on Climate Change, and the Convention on Biological Diversity. 
development to become a prime issue. ${ }^{24}$ However, the concept of sustainable development was not precised in Rio.

Principle 27 of the Rio Declaration on Environment and Development maintains that:

States and people shall cooperate in good faith and in a spirit of partnership in the fulfilment of the principles embodied in this Declaration and in the further development of international law in the field of sustainable development. ${ }^{25}$

In other words, States must work together in order to further develop the law of sustainable development. It must be underlined that one can only further develop something that already exists. Therefore, it can be argued that just four years after the first official appearance of sustainable development in the international community, it had already reached a legal status, even if only at a very initial stage. ${ }^{26}$

Has the concept of sustainable development evolved into a norm of international law since then? In order to answer this controversial question, we must analyse the state practice, the treaty law, the international case law and the legal literature related to the concept of sustainable development.

\section{State Practice, Treaty Law and Sustainable Development}

State practice and treaty law show an increasing presence of sustainable development. On the one hand, an important number of MEAs have increasingly embodied sustainable development in their texts since Rio. ${ }^{27}$ On the other hand, regional agreements such as the European Union (EU) have raised sustainable development to one of its top priorities. ${ }^{28}$ States world-wide specifically maintain that they want to establish sustainable policies domestically. ${ }^{29}$ Finally, also in nonenvironmental areas, such as the WTO itself, sustainable development is present. ${ }^{30}$

24 Convention on Biological Diversity, Rio de Janeiro, 5 June 1992, in force 29 December 1993, $31 \operatorname{ILM}$ (1992), at 818, Art. 2 and Art. 8 e).

25 UN Doc. A/CONF.151/26 (Vol. I), Rio Declaration on Environment and Development (1992), principle 27 (Emphasis added).

26 On this point see P. Sands, "International Law in the Field of Sustainable Development", 65 BYIL (1994), pp. 303-382, at 379.

27 See Convention on Biological Diversity... op. cit., Art. 2, Art. 8 e); Cartagena Protocol on Biosafety to the Convention on Biological Diversity, Montreal January 29, 2000, in force September 11, 2003, 39 ILM (2000), at 1027, preamble; Rotterdam Convention on the Prior Informed Consent Procedure for Certain Hazardous Chemicals and Pesticides in International Trade, Rotterdam September 10, 1998 preamble; Stockholm Convention on Persistent Organic Pollutants (POPs), Stockholm May 22, 2001, Art. 7.3 and Annex F, c) v.; United Nations Framework Convention on Climate Change, New York, 9 May 1992, in force 21 March 1994, 31 ILM (1992), at 849, preamble, Art. 3.4. Art. 2 and Art. 3.5; Kyoto Protocol to the United Nations Framework Convention on Climate Change, Kyoto, 10 December 1997, not in force, 37 ILM (1998), at 22, Art. 12.2; and International Tropical Timber Agreement, Geneva January 26, 1994, $33 \operatorname{ILM}(1994)$, at 1014, preamble.

$28 \quad$ See infra pp. 12.

29 For example, Argentina's Ministry for the Environment provides for a Sustainable Development and Environment Secretariat (Secretaría de Ambiente y Desarrollo Sustentable). 


\section{International Case Law and Sustainable Development}

International case law first dealt with sustainable development in 1997 in the Gabcikovo Nagymaros case before the International Court of Justice. ${ }^{31}$ While the final sentence does not clarify the legal nature of the concept, Judge Weeramantry in his separate opinion considered sustainable development 'to be more than a mere concept, but (..) a principle with normative value'. ${ }^{32}$ In other words, sustainable development is the framework in which environmental concerns can compromise with development interests.

\section{Legal Literature and Sustainable Development}

Legal literature gives different answers to the question about the nature of sustainable development. Some authors consider that it has already reached a normative status. ${ }^{33}$ Others believe that in specific environmental fields, such as fisheries for example, it not only has a legal nature, but it is also customary law. ${ }^{34}$ In between, other authors maintain that sustainable development still has to evolve in order to reach a normative status, notwithstanding its capacity to influence state's conduct. ${ }^{35}$

A fourth approach towards the legal nature of sustainable development is particularly interesting. According to Marong, sustainable development is becoming a public legitimate expectation that inevitably influences state's conduct. ${ }^{36}$ Sustainable development has developed from an abstract concept to a concrete tangible policy that citizens require of their governments. However, the author recognises that in many cases there still is not a strong response to the noncompliance of sustainable policies. Nevertheless, according to this approach, if the expectation

See also New Zealand's position on sustainable development in its Ministry for Environment webpage: "The New Zealand Government has agreed that sustainable development principles should underpin its economic, social and environmental policies at home, and abroad.", at http://www.mfe.govt.nz/issues/susdev/ (visited on October 28, 2004).

$30 \quad$ See infra pp. 11-12.

31 Case Concerning the Gabcikovo-Nagymaros Project (Hungary / Slovakia), 1997, printed in 37.1 ILM (1998) at 168. This dispute has been analysed by P. Sands, "International Courts and the Application of the Concept of "Sustainable Development", 3 Max Planck UNYB (1999), pp. 395-396.

32 Separate opinion of Judge Weeramantry in the Case Concerning the GabcikovoNagymaros Project (Hungary / Slovakia), 1997, printed in 37.1 ILM (1998) at 168 quoted in G. Pieratti \& J.L. Prat "Droit, économie, écologie et developpement durable: des relations nécessairement complémentaires ais inévitablement ambigues", Revue Juridique de l'Environnement (2000-3), p. 435, note 79. (Emphasis added)

33 See P. Sands... op. cit., p. 404, and D. Luff, op. cit., p. 94.

34 F. Ferrand, "Le développement soutenable: est-il une notion de droit international public?" in M. Bothe \& P.H. Sand eds La politique de l'environnement: De la réglementation aux instruments économiques Les livres de droit de l'Académie: The Hague / Boston / London; Martinus Nijhoff Publsihers (2003), pp. 266-268

35 This position is shared by Du Puy in relation to the precautionary principle; see P.M. Dupuy... op. cit., at 890.

36 A.B.M. Marong,.. op. cit. 
that flows from sustainable development increases, the concept will soon crystallize into a norm of international law. ${ }^{37}$

The debate on sustainable development not only involved single authors but also the ILA. As we have seen above, in 2002, the committee directed by Prof. Schrijver concluded its work on the Law of Sustainable Development approving the New Delhi Declaration. ${ }^{38}$ Notwithstanding the importance of this document, there is no clear outcome about the legal nature of sustainable development therein.

Thus, taking into account state practice, treaty law, international case law and relevant legal literature, we consider that sustainable development is not yet a norm of international law. Currently it reflects a policy goal of the international community. However, we are strongly convinced that some of the principles which form sustainable development, such as the precautionary principle and the common but differentiated responsibilities principle, are progressively developing into international law norms.

\section{Free Trade and Sustainable Development}

Until now we have maintained, on the one hand, that public international law can be used in the WTO and, on the other hand, that sustainable development per se is not an international legal norm, but that sustainable development principles are starting to achieve a normative status. The third goal of this paper is to see whether these principles may be useful in order to find a balance between TREMs in MEAs and WTO norms.

In order to reach a conclusion on this point, we consider that the conceptual relationship between free trade and sustainable development must be highlighted. As Brown Weiss already maintained in 1992: 'Trade is not an end in itself, it is a mean to an end. The end is environmentally sustainable economic development. ${ }^{39}$ In other words, the final goal of free trade must be the achievement of sustainable development. This part of the paper will analyse the role of sustainable development in the WTO and in the EU in order to determine if the abovementioned conceptual relationship has been adopted therein.

\section{A. Sustainable Development and the World Trade Organization}

Sustainable development is present in the Marrakech Agreement preamble as one of the goals of the organisation. ${ }^{40}$ Even if a preamble does not have the same strength as the text of a treaty, its wording is important for the interpretation of the overall Agreement. ${ }^{41}$ In the Shrimp Turtle decision the Appellate Body maintained that: '[the] preambular language reflects the intentions of negotiators of the WTO Agreement, [and] it must add colour, texture and shading to our

\footnotetext{
$37 \quad$ Ibid, at 69-70.

$38 \quad$ See supra pp. 6-7.

39 E. Brown Weiss, "Environment and Trade as Partners in Sustainable Development: A Commentary", 86.4 AJIL (1992), pp. 728-735. Authors as H. Ward, "Common but differentiated debates: Environment, Labour and the World Trade Organisation”, 45.3 ICLQ (1996), p. 595; and A.H. Ansari, "Free Trade Law and Environmental Law: Congruity or Conflict?", 41.1 Ind. J. Int'l L. (2001), p. 1, agree with E. Brown Weiss' position.

$40 \quad$ Marrakech Agreement Establishing the World Trade Organisation, 15 of April, 1994, § 1.

41 Vienna Convention on the Law of Treaties... op. cit. , Art. 31.2.
} 
interpretation of the agreements annexed to the WTO Agreement, ... ${ }^{42}$ The WTO compromise with sustainable development has been reaffirmed in the Doha round of negotiations, which have been called the Development Round. The Doha Ministerial Declaration clearly highlights the importance of sustainable development for the WTO. ${ }^{43}$

Sustainable development is therefore present in the WTO preamble and in the Doha Ministerial Declaration. But what is the status of sustainable development according to the multilateral trading system? Is it a legal norm or just a political guideline? The answer is quite clear. The WTO does not believe in the legal nature of sustainable development and of its principles. This conclusion can be drawn from the analysis of the Hormones case ${ }^{44}$ in which the Appellate Body maintained that 'whether it [the precautionary principle] has been widely accepted by Members as a principle of general or customary international law appears less than clear. ${ }^{45}$

However, the decision in the Asbestos case ${ }^{46}$ has been considered as a slight change in direction of the WTO jurisprudence on sustainable development principles. In this last dispute the Appellate Body decided in favour of a French ban on asbestos and asbestos-containing products, which was inspired by the precautionary principle. The future decision on the dispute about genetically modified product imports in the European market between the United States of America, Argentina and Canada, on one side, and the EU, on the other, ${ }^{47}$ might determine the current state of the WTO case law on sustainable development law principles, such as the precautionary principle. ${ }^{48}$

\section{B. Sustainable Development and the European Union}

How has sustainable development been dealt with in the EU? Art. 6 of the Treaty Establishing the European Community reads: 'Environmental protection requirements must be integrated into (...) Community policies (...), in particular with a view to promoting sustainable development'.

42 Doc. WT/DS58/AB/R: Appellate Body Report United States - Import Prohibition of Certain Shrimp and Shrimp Products, 1998, § 153, (italic emphasis in the original).

43 Doc. WT/MIN(01)/DEC/120, Doha Ministerial Declaration, November 2001, $§ 6$.

44 Doc. WT/DS26/AB/R: Appellate Body Report EC Measures Concerning Meat and Meat Products (Hormones), 1998.

$45 \quad$ Ibid, $\S 123$. (Emphasis added)

46 Doc. WT/DS135/AB/R: Appellate Body Report: European Communities - Measures Affecting Asbestos and Asbestos-Containing Products, 2001, printed in 40.5 ILM (2001) at 1193.

47 Doc. WT/DS29: European Communities - Measures Affecting the Approval and Marketing of Biotech Products (2004).

48 See J. Scott, European Regulation of GMOs: Thinking about 'Judicial Review' in the WTO, Jean Monnet Working Paper $\mathrm{N}^{\circ}$ 04/2004, available at http://www.jeanmonnetprogram.org/papers/04/040401.html; and D. Brack, R. Falkner \& J. Goll, The next trade war? GM products, the Cartagena Protocol and the WTO, The Royal Institute for International Affairs Briefing Paper $\mathrm{N}^{\circ} 8$ (2003), available at http://www.riia.org/pdf/research/sdp/Next\%20trade\%20war\%20GM\%20\%20CP\%20\&\%20WTO \%20Brack\%20et\%20al\%20Sept\%2003.pdf; and G.E. Isaac \& W.A. Kerr, "Genetically Modified Organism at the World Trade Organization: A Harvest of Trouble", 37.6 JWT (2003), pp. 10831095. 
This implies that all European policies, including commercial policies, ${ }^{49}$ must be established and applied taking into account sustainable development. Underlining that the WTO and the EU are different, one still has to agree that one of the goals of the EU is to foster free trade, just as in the multilateral trading system. Therefore, the EU is an example of an organisation in which trade is an instrument to promote sustainable development.

\section{Conclusions}

My first conclusion, then, is that free trade must not be treated as a goal in itself: it is a means for reaching a goal. The same applies for the protection of the environment. The goal for both is sustainable development.

Therefore, sustainable development must be the framework within which the whole trade and environment debate, and not only the question of the relationship between Trade measures in MEAs and the WTO, should be held.

My second conclusion is that international law can be used in a WTO dispute and that specific sustainable development principles have already developed into norms of international law.

Therefore, if a TREM in an MEA leads to a dispute before the WTO, panels and appellate bodies will have to decide not only through the application of WTO law, but also by applying international law and sustainable development principles that are relevant to the dispute.

This will be particularly important in the future relationship of the Cartagena Biosafety Protocol and of the climate regime instruments with the multilateral trading system. In fact, in both regimes key States are non-parties and it is likely that trade measures must be envisioned in order to efficiently regulate trade in genetically modified organisms and in order to seriously tackle climate change.

In conclusion, a year ago John D. Graham, a member of the Bush Administration, referred to the precautionary principle in the following way: 'We consider it to be a mythical concept, perhaps like a unicorn. ${ }^{50}$ I hope that more and more people will start to believe in unicorns and the world in which they live, the world of sustainable development.

49 One of the Community policies to which Art. 6 refers is the Common commercial policy, provided for in Title IX of the Treaty Establishing the European Community.

The New York Times, May 18, 2003. 